\title{
Effective Planning and Organisational Productivity. (A Case Study Of Sterling Bank Nigeria Plc).
}

\author{
${ }^{1}$ Olusanya, Samuel Olumuyiwa, ${ }^{2}$ Awotungase, Suleiman Adelaja, \\ ${ }^{3}$ Ohadebere Emmanuel Chukwuemeka \\ ${ }^{1}$ Lecturer Lagos State University External System, Nigeria.Economics Department \\ ${ }^{2}$ Lecturer Lagos State University External System Business Administration Department Associate Lecturer \\ Saint Augustines' College Of Education Akoka \\ ${ }^{3}$ Lecturer Lagos State University External System Banking And Finance Department
}

\begin{abstract}
The research study takes a look at the impact of effective Planning on Organizational Productivity using Sterling bank Nigeria Plc as a case study. However, the research study makes use of primary data of questionnaire analysis and the estimation technique adopted in the study is spearman's rank correlation coefficient and the objectives of the study is to determine the relationship between effective planning and organizational productivity and to also to examine whether effective Planning leads to employees performance in an organization. More over, two hypotheses were tested using the spearman's rank correlation coefficient and the results revealed that effective planning has a relationship with organizational productivity and that effective planning lead to employee's performance in an organization. Therefore, the study concludes and recommends that managers time and attention is that of improving productivity in Sterling bank is very important for both survival and maintenance of profit margins in the bank, therefore the bank should measure productivity on how well resources are combined and utilized to accomplish specific desirable results to be able to achieve its objectives on organizational need, articulate its strategies and carefully pursue them.
\end{abstract}

Key words: Effective Planning, Productivity, Sterling bank, Employees' Performance, Organizational Objective.

\section{Introduction}

In majority of organization in Nigeria, planning is the most important management tool for performance and for organizations to perform well, resources must be well utilized and customers well served. To achieve such ends, all of an organization's human and materials resources must be well utilized in the right way and the right time to create high quality products at minimal cost.

Formally defined, productivity is a summary measure of the quantity and quality of work performance, with resources utilization taken into account. It can be measured at the individual, group, or organizations level, Productivity may be expressed as success into dimensions of organizations performance, effectiveness and efficiency.

Organization has been collective in order to achieve group or individual objectives. They serve as the means by which goods and services are provided beyond the boundaries of an individual or small group's capacity of self-sufficiency. Such provision, also acknowledged, may be made for profit through some other more controlled framework of commercial or social provision (Dawson 1996).

However, Planning on the other hand, is regarded as the most basic of all the management functions. It involves the selecting from among alternative future course of action for the organization as a whole and every department or section within it. Furthermore, it requires selecting organizational objectives and departmental goals, determines and provides a rational approach to pre-selected objectives. It strongly implies managerial innovation and the ability to create something (koontz 1980).

The problem which underscores the need to undertake this study is aptly described by Koontz et al (1980) with all the interest in planning and all the sense of urgency brought about by modern super competition, is the danger that planning can become merely a costly fad, not very useful and even disillusioning. The implication of the above assertion is that not all organization that plan eventually reaps the desired benefits. Schermerhorn (1986) adds that most planning failures arise from their inability of managers to truly understand the planning and to implement it well. Problems have been identified in the planning process. For instance, insetting objectives, organizations find it difficult to involve employees, shareholders, customers etc. closely related to this is the issue associated with the likely environment different variables and events. However, the objectives of the study is to determine the relationship between effective planning and organizational productivity and to also examine whether effective Planning brings employees performance in an organization. 


\section{Brief Literature Review}

An important aspect of the managerial revolution of the past four decades has been said to be the tremendous interest in planning by all forms of enterprise such as business, government, educational institutions and others. The importance of planning in areas such as factory operations has been stressed many years earlier. For instance, production managers discovered early that without planning, their mistakes showed up within days, as production line came to a halt because of a misfit part or the absence of a needed component.

The idea of organization planning, had been conceptualized as far back as the 1940's by Goetz(1949), who stressed that planning is fundamentally choosing and "planning problems arise only when an alternative course of action is discovered." As such, Goetz saw planning as being inextricable linked with decisionmaking. But Koontz et al (1980) conceives planning to be much more than essentially decision-making. According to them, planning presupposed the existence of alternatives, and that there are very few decisions for which some kind of alternative does not exist. They state further that planning is deciding in advance what to do, how to do it, when to do it, and who is to do it. As the most basic of all managerial functions, planning involves selecting from among alternatives, future courses of action for the enterprise as a whole and for every depart mental goals and determining ways of achieving them. The authors argue that planning must involve an opensystem approach to managing. This is because planning cannot be taken in a vacuum. Rather, it must consider the nature of the future environment in which planning decisions and actions are intended to operate.

Stoner (1982) offers that planning is a process that does not end when a plan is agreed upon rather, it must be implemented. Also at any time during the implantation and control process, plans may require modification to avoid becoming useless or even damaging Stoners argument therefore, implies that decisions must be made at many points in the planning process. For instance, managers must decide which predictions in such areas as the economy, and the actions of competitions are likely to be most accurate. They must also analyze organizational resources and decide how to allocate them to achieve their goals most effectively. Again, Koontz et al (1980) introduces an issue known as the nature of planning which can be highlighted by for aspects of planning. These aspects are contributions to purpose and objectives' primacy of planning, pervasiveness of planning and efficiency of plans. These aspects are discussed briefly in turn.

Contribution to purpose and objectives- Drawing mainly from work of Goetz (1949), Koontz and his colleagues assert that the purpose of every plan and all derivative plan is to facilitate the accomplishment of enterprise purpose and objectives. Primary of planning, pervasiveness of planning and efficiency of plans are discussed briefly in turn. This principle derives from the nature of organized enterprise, which exists for the accomplishment of group purpose through deliberate accomplishment of group through cooperation.

Primary of planning- It is argued that since managerial operations is organizing, staffing, treating and controlling are designed to support the accomplishment of enterprise objectives, then planning should logically precede the execution of all other managerial functions. Although all the managerial functions are interlinked in practice as a system of action, planning is unique, in that it establishes the objective necessary for all group effort. Besides, it is argued that plans must be made to accomplish these objectives before the manager knows what kind of organization relationships and personal qualifications are needed, along which course subordinates are to be directed and led, what control is to be applied. Most important, all the other managerial functions must be planned if they are to be effective.

Pervasiveness of planning- This implies that planning is a function of all managers, although the character and breadth of planning will vary with the nature of policies and plans authorized by their superiors. However, one manager because of his authority or position in the organization may do more planning or more important planning or another, or the planning of one may be more basic and applicable to a large portion of enterprises than that of another.

Efficiency of plans- This concept stresses that a plan is efficient when it contributes to purpose and objectives as offset by the cost and other unsought consequences required to formulate and operate such plans. As such a plan too high attracts unnecessarily high costs.

Also, even though the concepts of efficiency implies the normal ratio of input to output in terms of money, labor hours or units of production to include such values as individual and group satisfaction. In all, it can be concluded that if managers do not plan to some degree, they would have no idea of whether or not the organization is accomplishing its purpose. Dixon (1970) provides four reasons why planning is important for good management. They are as follows:

1) Planning aids the process of control, because mangers have a benchmark against which they can measure the actual results achieved.

2) Planning helps to make the operations of organization more economical. 
3) Planning focuses attention on the organization's real objectives.

4) Planning helps to offset the effects of uncertainty and change.

He however, warns that this does not imply that planning remove, or even transcend the presence of risk, but it does make managers more aware of the risk involved.

However, Plans emerge or are formulated during the planning process. These plans also differ. In fact it has been argued that failure of some managers to recognize that variety of plans has often caused difficulty in making planning effective.

Koontz at el (1980) typologies plans as purpose or missions, objectives, strategies, policies, rules, procedures, programmes and budgets.

They are however, very cautious in categorizing plans based on some rigid time frames. According to them, the time frame allocated to a particular plan depends largely on what they term "the commitment principle" this principle states that logical planning encompasses a period of time in the future necessary to foresee, as much as possible the fulfillment of commitment involved in decisions made today. They basic assumption upon which this principle rests is that, since in general planning and the forecasting that underlies it is costly, an organization should probably not plan for a longer period than is economically justifiable. Yet it is risky and wasteful to plan for a shorter period.

According to J.Aitag he went further to explain what planning is all about and also what are the levels of planning which means all managers participate in the planning process to some degree. Participation in the planning process will depend on the size and the goal of the firm and the specific function of the manager.

\section{Three Important Parts Of Planning}

He further explains that planning horizon is an important part of any plan in the planning horizon, the length of time the plan specifies for activities to be carried out. Three planning horizon can be identified: long range, intermediate and short range.

Long-range planning- Involves identifying those activities to be performed over an extended period of time. Long range plan may extend for several decades. Long range planning is different from strategic planning, which is primarily concerned with how the organization will position itself among competing firms in a market. Long-range planning identifies the activities to be performed that will lead to the accomplishment of official goals. One important feature, a long-range plan is necessarily different from shorter planning horizons in a plan covering 20 years.

Intermediate Planning- Identifies activities o be carried out over a period of five years at the middle levels of the organization. Intermediate planning is critical in most cases to the success. Intermediate planning is focused more on the activities that have to be carried out with a planning horizon that contains fewer uncertainties.

Short-range Planning: Developing plans for implementation within a planning horizon of less than one year is often referred to as short-range planning. Short-range plans may specify activities to be carried out that will achieve certain production levels each week. While short-range plans are necessary for most organizations, they can have drawbacks. Often managers become so focused on short-range plans. Ultimately, this can lead to failure in the accomplishment of organizational goals.

There are several steps in planning process used by large, diversified corporation.

Statement of official goals: The chief executive of the firm sets the official goals usually presenting them to division heads. A formal statement of the official goals provides a common focus for planning and identifies those goals that top management seek to emphasize.

Development of the Divisional plans: Divisional mangers receive copies of the official goals and begin divisional plans. Operative goals are identified that support the official goals.

Consolidation of the Divisional and departmental plans: Each division submits its plans to top management, which then consolidates the divisional objectives into consistent 'package' across divisions. In this step top management may either reject plans, accept plans in the plans submitted by the divisions.

Co-ordination of the Divisional plans: After preparation of the divisional plans has been completed, the plans are returned to top management. Top management aggregates the divisional plans, checks computation and evaluates the plans based on financial criteria. 
Integration of divisional Budgets: The completion of divisional budgets leads to the final step where the budgets are submitted to top management. Top management reviews the budgets but rarely rejects them. Who? It is often felt that top management does not have detailed knowledge of operations at the lower levels of the cooperation to make a critical examination of those plans. According to Schermerhom the process of management involves planning, organizing, leading, and controlling. The first of these functions, planning, set the stage for the others. It is a process of deciding exactly what one wants to accomplish and how to go about it. When planning is done well, it creates a solid platform for further management efforts at organizing, allocating, and arranging resources to accomplish essential tasks. The planning process identifies the specific result or desired outcome of the planning as a statement of action steps to be taken in order to accomplish the objectives.

Step 1 Define your objective, identify desired outcome or results in any specific ways, know where you want to go, be specific enough that you will know you have arrived when you get there or know how far off the mark you are at various points along the way.

Step 2 Determine where you start vis-à-vis objectives. Evaluate current accomplishments to the desired results, know what strengths work in you favour and weakness may hold you back.

Step 3 Develop premises regarding future conditions. Try to anticipate future events, generate alternative 'scenarios' for what may happen for each scenario, things that may help towards your objectives.

Step 4 Analyze possible action alternatives, choose the best among them and decide how to implement. List and carefully evaluate the possible actions that may be taken, chosen the alternative most likely to accomplish your objectives.

Step 5 Implement the plan and evaluate results. Take action and carefully measure your progress toward objectives. Do what the plan as needed. He further explains that a strategic plan is comprehensive and addresses long-term needs and directions of the organization while an operational plan is of limited scope and addresses activities to implement strategic plans and achieve strategic objectives. While plan tools and techniques are clearly essential to the success of the management process, the benefits, however, are most often realized when the planning approaches are comprehensive and the foundations are well established. In the latter regards, the useful planning tools and techniques include forecasting, the use of scenarios, benchmarking, participative planning and the use of staff planners. Forecasting is the process of making assumptions about what will happen in the future. All good plans involve forecasts. In the final analysis, forecasting always relies on human judgment.

\section{Productivity In An Organization}

One of the most important issues facing the applied behavioral sciences is that of human productivity, the quality and quantity of work. Productivity concerns both effectiveness and efficiency. According to Peter Drucker a founding father of management theory wrote, effectiveness is a minimum condition for survival after success has been achieved. Efficiency is concerned with doing things right and effectiveness is doing the right things. In discussing effectiveness, we must once again distinguish between management and leadership. As we discussed earlier, leadership is a broad concept than management. Management is thought of as a special kind of leadership in which the accomplishment of organizational goals is paramount. Leadership is an attempt to influence people, individual and in groups, for whatever reason. Influence and leadership may be used interchangeably. According to Parkinson's Law which suggests a clear example of a person placing personal goals before organizational goals. His law states that in bureaucracies, managers often try to build up their own departments by adding unnecessary personnel and more equipment. Although this tendency may increase the prestige and importance of the managers. This, in discussing effectiveness, we must recognize the differences between individual goals, organizational goals, leadership and management. So their successes measured by the output or productivity of the group they lead, with that thought in mind, Bernard Bass suggested a clear distinction between successful and effective leadership and management. Success has to do with how the individual or the group behaves; on the other hand effectiveness describes the internal sate of an individual and thus, it is attitudinal in nature individuals who are interested only in success tend to emphasize their position power and use close supervision. Effective individuals however, will also depend on personal power and use more general supervision position power tends to be delegated down through the organization, while personal power is generated upward from below through follower acceptance.

According to Fred Luthans, a professor of management at the university of Nebraska, who conducted a four-year observational study to determine similarities and differences between successful managers spent more of their time and effort networking with others inside and outside the organization than did effective managers. In the management of organizations, the difference between successful and effective often explain why may supervisors can get a satisfactory level of output only when they are right there looking over a worker's shoulder. In summary, managers could be successful but ineffective having only a short-lived influence over the behavior of others. It should be pointed out that this successful; versus effective framework is a way of evaluating the response to a specific behavioral event and not of evaluating performance over time. And so what 
comes in mind is what determines organizational effectiveness. In discussing effectiveness we have concentrated on evaluating the results of individual leaders or managers. We are concerned not only with the outcome of a given leadership attempt but also with the effectiveness of the organizational unit over a period of time. Causal variables are those factors that influence the course of development within organizations and its results. These independents variables can be altered by the organization and its management, leadership strategies, skill and behavior. Management decisions and the policies and structure of the organization are examples of causal variables. Output or end result variables are the variables that reflect the achievements of the organization. The effectiveness of managers is often determined by net profits.

\section{Methodology}

The research methodology for this study will be basically primary data of questionnaire analysis and Spearman's rank correlation coefficient as the estimation technique. However, questionnaire was distributed to one hundred and twenty (120) staff of Sterling bank Nigeria Plc but only one hundred (100) respondents (staff of Sterling bank Nigeria Plc) returned back the copy of their questionnaire. Therefore, the one hundred questionnaires were administered and the result was used to test for the two hypotheses formulated for this study.

However, the formular for Spearman's rank correlation coefficient is as follows;

$\mathrm{R}=1-\frac{6 \sum \mathrm{d}^{2}}{\mathrm{n}\left(\mathrm{n}^{2}-1\right)}$

Where $d=$ the difference between the ranks of each pair.

$\mathrm{n}=$ number of paired observations

\begin{tabular}{|l|l|}
\hline Correlation Range & Strength of Association \\
\hline \pm 0.70 to $\pm \mathbf{1 . 0 0}$ & Strong \\
\hline \pm 0.40 to $\pm \mathbf{0 . 6 9}$ & Moderate \\
\hline \pm 0.25 to $\pm \mathbf{0 . 3 9}$ & Weak \\
\hline \pm 0.10 to $\pm \mathbf{0 . 2 4}$ & Very Weak \\
\hline \pm 0.00 to $\pm \mathbf{0 . 0 9}$ & None \\
\hline
\end{tabular}

Source: Nyang, (2005).

HYPOTHESIS ONE

\section{Research Hypotheses}

Null Hypothesis (Ho): Effective planning has no relationship with organizational productivity.

Alternative Hypothesis (Hi): Effective planning has a relationship with organizational productivity.

HYPOTHESIS TWO

Null Hypothesis (Ho): Effective Planning does not lead to employee's performance in an organization.

Alternative Hypothesis (Hi): Effective planning lead to employee's performance in an organization.

ANALYSIS

Table 1

\section{SEX DISTRIBUTION}

\begin{tabular}{|l|l|l|l|}
\hline RESPONSES & FREQUENCY & \% & CF \\
\hline Male & 76 & 76 & $\mathbf{7 6 . 0}$ \\
\hline Female & 24 & 24 & 100.0 \\
\hline Total & 100 & 100 & \\
\hline
\end{tabular}

Source: Field Survey 2012

The result above shows that 76 out of 100 respondents are male and this gives $76 \%$ of the whole respondents while 24 out of 100 respondents are female and this constitutes $24 \%$ of the total respondent. We can then conclude that there are more male than female respondents in the research study.

Table 2

MARITAL STATUS DISTRIBUTION

\begin{tabular}{|l|l|l|l|}
\hline RESPONSES & FREQUENCY & $\%$ & CF \\
\hline Single & 28 & 28 & $\mathbf{2 8 . 0}$ \\
\hline Married & 52 & 52 & $\mathbf{8 0 . 0}$ \\
\hline Divorced & 20 & 20 & 100.0 \\
\hline Total & 100 & 100 & \\
\hline
\end{tabular}

Source: Field survey 2012 
The table 2 above shows that 28 out of 100 respondents are single and it gives $28 \%$ of the total respondents, 52 out of 100 respondents is married and this gives $52 \%$ of the whole respondents while 20 out of 100 respondents are divorced and this represent $20 \%$ of the total respondents. Therefore we can then conclude from the analysis that there are more married than single respondents in the research study.

Table 3

AGE DISTRIBUTION
\begin{tabular}{|l|l|l|l|}
\hline RESPONSES & FREQUENCY & $\%$ & CF \\
\hline Below 25 years & 24 & 24 & $\mathbf{2 4 . 0}$ \\
\hline Between 25-35 years & 62 & 62 & $\mathbf{8 6 . 0}$ \\
\hline Between 36-45 vears & 12 & 12 & 98.0 \\
\hline 46 and above & 2 & 2 & $\mathbf{1 0 0 . 0}$ \\
\hline Total & 100 & 100 & \\
\hline
\end{tabular}

Source: Field survey 2012

The result above reveals that 24 out of 100 respondents are below 25 years and this represent $24 \%$ of the whole respondents, 62 out of 100 respondents are between the age 25-35 years and this constitutes $62 \%$ of the total respondents 12 out of 100 respondents are between the age $36-45$ years and this represent $12 \%$ of the total respondents while only two respondent is 46 years and above and this gives $2 \%$.

Therefore, we can then conclude that there are more respondents between the ages 25-35 years in the research study.

Table 4

EDUCATIONAL QUALIFICATION DISTRIBUTION
\begin{tabular}{|l|l|l|l|}
\hline RESPONSES & FREQUENCY & $\%$ & CF \\
\hline WAEC & 4 & 4 & 4.0 \\
\hline NCE/OND & 30 & 30 & 34.0 \\
\hline HND/B.SC & 44 & 44 & 78.0 \\
\hline M.Sc./MBA & 22 & 22 & 100.0 \\
\hline Total & 100 & 100 & \\
\hline
\end{tabular}

Source: Field survey 2012

The result above reveals that 4 respondents have WAEC qualification and this gives $4 \%$ of whole respondents, 30 respondents have NCE/OND qualification and this gives $30 \%$ of the total respondents. However, 44 respondents have HND/BSC qualification and this represent $44 \%$ if the whole respondents while 22 respondents have MSC/MBA qualification and it give $22 \%$ of the total respondents. Therefore, we can then conclude that respondents that have HND /BSC qualification are more in the research study.

Result Of General Questions Distributed To The Respondents

\begin{tabular}{|c|c|c|c|c|}
\hline Questions & Response & Frequency & $\begin{array}{l}\text { Cumulative } \\
\text { Frequency }\end{array}$ & Percentage (\%) \\
\hline $\begin{array}{l}\text { 1. Your Bank gives } \\
\text { cognance to Panning } \\
\text { programme }\end{array}$ & $\begin{array}{l}\text { COLUMN } \\
\text { SA } \\
\text { A } \\
\text { SD } \\
\text { D }\end{array}$ & $\begin{array}{l}100 \\
- \\
- \\
-\end{array}$ & 100.0 & $100 \%$ \\
\hline $\begin{array}{l}\text { 2. The Staff of the bank } \\
\text { are usually send for } \\
\text { training on effective } \\
\text { Planning programme. }\end{array}$ & $\begin{array}{l}\text { SA } \\
\text { A } \\
\text { SD } \\
\text { D }\end{array}$ & $\begin{array}{c}67 \\
- \\
33 \\
-\end{array}$ & $\begin{array}{l}67.0 \\
- \\
100.0 \\
-\end{array}$ & $\begin{array}{l}67 \% \\
- \\
33 \% \\
-\end{array}$ \\
\hline $\begin{array}{l}\text { 3.To-Do-list Planning, } \\
\text { operational Planning and } \\
\text { Strategic Planning are } \\
\text { Planning method used in } \\
\text { Sterling bank }\end{array}$ & $\begin{array}{l}\text { SA } \\
\text { A } \\
\text { SD } \\
\text { D }\end{array}$ & $\begin{array}{c}43 \\
37 \\
10 \\
10\end{array}$ & $\begin{array}{l}40.0 \\
80.0 \\
90.0 \\
100.0\end{array}$ & $\begin{array}{l}43 \% \\
37 \% \\
10 \% \\
10 \%\end{array}$ \\
\hline
\end{tabular}




\begin{tabular}{|c|c|c|c|c|}
\hline $\begin{array}{l}\text { 4. The Planning } \\
\text { programmes are usually } \\
\text { relevant to your job } \\
\text { Performance in sterling } \\
\text { bank. }\end{array}$ & $\begin{array}{l}\text { SA } \\
\text { A } \\
\text { SD } \\
\text { D }\end{array}$ & $\begin{array}{l}100 \\
- \\
- \\
-\end{array}$ & 100.0 & $100 \%$ \\
\hline $\begin{array}{l}\text { 5. Your bank Develop } \\
\text { methodologies for Job } \\
\text { specification which are } \\
\text { more efficient and } \\
\text { thorough in carry out } \\
\text { your work. }\end{array}$ & $\begin{array}{l}\text { SA } \\
\text { A } \\
\text { SD } \\
\text { D }\end{array}$ & $\begin{array}{l}45 \\
25 \\
30 \\
-\end{array}$ & $\begin{array}{r}45.0 \\
70.0 \\
100.0\end{array}$ & $\begin{array}{l}45 \% \\
25 \% \\
30 \%\end{array}$ \\
\hline $\begin{array}{l}\text { 6. Through Effective } \\
\text { Planning Your bank } \\
\text { Develop superior quality } \\
\text { assurance mechanisms } \\
\text { that provide greater } \\
\text { confidence and } \\
\text { reassurance to clients and }\end{array}$ & $\begin{array}{l}\text { SA } \\
\text { A } \\
\text { SD } \\
\text { D }\end{array}$ & $\begin{array}{l}100 \\
- \\
- \\
-\end{array}$ & 100.0 & $100 \%$ \\
\hline $\begin{array}{l}\text { 7. Long and Short-Term } \\
\text { Planning is the best in the } \\
\text { banking industry. }\end{array}$ & $\begin{array}{l}\text { SA } \\
\text { A } \\
\text { SD } \\
\text { D } \\
\end{array}$ & $\begin{array}{l}100 \\
- \\
- \\
- \\
\end{array}$ & 100.0 & $100 \%$ \\
\hline $\begin{array}{l}\text { 8. There is Central } \\
\text { Planning department in } \\
\text { Sterling bank. }\end{array}$ & $\begin{array}{l}\text { SA } \\
\text { A } \\
\text { SD } \\
\text { D }\end{array}$ & $\begin{array}{r}64 \\
36 \\
- \\
-\end{array}$ & $\begin{array}{r}64.0 \\
100.0\end{array}$ & $\begin{array}{l}64 \% \\
36 \%\end{array}$ \\
\hline $\begin{array}{l}\text { 9. Through Effective } \\
\text { Planning in your bank, } \\
\text { organizational Goal and } \\
\text { Objectives have been } \\
\text { achieved. }\end{array}$ & $\begin{array}{l}\text { SA } \\
\text { A } \\
\text { SD } \\
\text { D }\end{array}$ & $\begin{array}{l}100 \\
- \\
- \\
-\end{array}$ & 100.0 & $100 \%$ \\
\hline $\begin{array}{l}\text { 10. Effective Planning } \\
\text { has improve customers' } \\
\text { patronage in Sterling } \\
\text { bank. }\end{array}$ & $\begin{array}{l}\text { SA } \\
\text { A } \\
\text { SD } \\
\text { D }\end{array}$ & $\begin{array}{l}100 \\
- \\
-\end{array}$ & 100.0 & 100 \\
\hline $\begin{array}{l}\text { 11. Productivity } \\
\text { Sterling bank can } \\
\text { rated to Very High. }\end{array}$ & $\begin{array}{l}\text { SA } \\
\text { A } \\
\text { SD } \\
\text { D } \\
\end{array}$ & 100 & 100.0 & $100 \%$ \\
\hline $\begin{array}{l}\text { 12. There are adequate } \\
\text { Planning Supervisors in } \\
\text { your bank. }\end{array}$ & $\begin{array}{l}\text { SA } \\
\text { A } \\
\text { SD } \\
\text { D }\end{array}$ & $\begin{array}{c}72 \\
28\end{array}$ & $\begin{array}{r}72.0 \\
100.0\end{array}$ & $\begin{array}{l}72 \% \\
28 \%\end{array}$ \\
\hline $\begin{array}{lr}\text { 13. Adequate } & \text { Training } \\
\text { and Development of Staff } \\
\text { on effective Planning has } \\
\text { improved } \\
\begin{array}{l}\text { Performance in your } \\
\text { bank. }\end{array}\end{array}$ & $\begin{array}{l}\text { SA } \\
\text { A } \\
\text { SD } \\
\text { D }\end{array}$ & $\begin{array}{l}65 \\
- \\
- \\
35\end{array}$ & $\begin{array}{l}65.0 \\
- \\
- \\
100.0\end{array}$ & $\begin{array}{l}65 \% \\
35 \%\end{array}$ \\
\hline $\begin{array}{l}\text { 14. Effective planning has } \\
\text { a relationship with } \\
\text { organizational } \\
\text { productivity. }\end{array}$ & $\begin{array}{l}\text { SA } \\
\text { A } \\
\text { SD } \\
\text { D } \\
\end{array}$ & $\begin{array}{l}52 \\
- \\
- \\
48 \\
\end{array}$ & $\begin{array}{r}52.0 \\
100.0 \\
\end{array}$ & $\begin{array}{r}52 \% \\
48 \% \\
\end{array}$ \\
\hline $\begin{array}{l}\text { 15. Effective Planning } \\
\text { lead to employee's } \\
\text { performance in an } \\
\text { organization. }\end{array}$ & $\begin{array}{l}\text { SA } \\
\text { A } \\
\text { SD } \\
\text { D } \\
\end{array}$ & $\begin{array}{c}66 \\
34\end{array}$ & $\begin{array}{r}66.0 \\
100.0\end{array}$ & $\begin{array}{l}66 \% \\
34 \%\end{array}$ \\
\hline Total & & 100 & & 100.0 \\
\hline
\end{tabular}

Source: Field survey 2012 


\section{Where SA- Strongly Agree, A- Agree, SD- Strongly Disagree, D- Disagree. Base on the result above, we can conclude that Sterling bank Nigeria Plc take cognize of effective planning to achieve organizational productivity.}

\section{Recommendations \\ *Identify Better Candidates}

VII. Recommendation And Conclusion

Identifying candidates is not just a matter of sitting down with an organization chart. It requires meetings and discussions with leaders and if possible a representative from human resources. This crossfunctional team identifies skill needed for a particular role and then identifies employees who have those competencies. Chances are there will not be a perfect match for each position, but this discussion will give you an idea of what is needed, who is available and allow you to put a plan in place to bridge any gaps.

\section{*Communicate}

Do not plan successors in secret. It is important for the organization and individuals to know the leadership team takes employee development and succession planning seriously. Although you won't want to tell an employee that she is a definite replacement for a particular role, you will want to ask the candidate what her career aspirations are and work with her to develop the skills necessary to fill the identified role.

\section{*Develop Talent}

Once a successor is identified and a conversation has taken place to ensure he is interested in such a promotion, put a step-by-step plan in place to develop this individual. Training, more responsibility, more autonomy, a broader understanding of the business are some potential areas to identify and create plans to address. Providing feedback and encouragement to potential successors is an important step in the whole planning process.

\section{*Implementation}

Many organizations go through the rigors of identifying candidates, but not the more arduous task of developing talent and finally implementation. If done properly, there should be trained and eager employees able to step into vacancies left by departing leaders. This quick response prevents the company from being vulnerable during transition as well as making change far less tumultuous on everyone.

\section{*Ongoing}

Succession planning must have the support and backing of the company's senior level management and the human resources department. One meeting to identify candidates is not enough to ensure proper succession occurs. It is necessary to have an ongoing process to identify needed competencies, necessary candidates and a plan to combine the two. Ongoing work is also necessary if a potential candidate moves into another position or out of the organization.

\section{Conclusion}

On the key issues that vie for managers time and attention is that of improving productivity this is very important for both survival and maintenance of profit margins. Productivity is a measure of how well resources are combined and utilized to accomplish specific desirable results to be able to achieve its objectives on organization need articulate its strategies and carefully pursue them. There is no gain saying therefore that the success or otherwise of any organization depends on how effective their plans are.

The service industry offers intangible products, hence its efficiency and effectiveness can only be measured in terms of how well its service are delivered to its various publics. In recent years, the banking sector has witnessed tremendous growth. In fact, the sector is said to be the most active within the economy. Incidentally while the banking sector was booming there was recession in most other sectors of the economy. In other words, there was no commensurate growth. The completed deregulation of the banking sector made entry relatively easy.

Similarly, the rate collapse/demise also became high and this is traceable to poor environment analysis and lack of adequate planning on the part of the banks. The uncertainty inherent in the business environment makes it imperative that for any organization to succeed it must not only plan but vigorously implement and monitor such Plans. 


\section{REFRENCES}

[1] Asika, N. (1991) Research Methodology in the Behavioral Services, a textbook 2nd edition, pg 33-45, Longman Publication Limited, Lagos.

[2] Amaratunga, D., Baldry, D., Sarshar, M. and Newton, R (2002), Quantitative and qualitativeresearch in the built environment, Work Study, Vol. 51, No.1.

[3] Aldag, R.J and Stearus, T.M. (1991) Measurement Skill, a textbook, 4th edition pg 122-135 South-Western Publishing Company, Cincinnati, Ohio USA.

[4] Bernard M. (1960) Bass in Leadership, Psychology and Organizational Behaviour, a textbook 2nd edition, pg 88-89, New York Harper and Brothers Publication.

[5] Bowditch J. and Buono, A. (1997) A Primer of Organizational Behaviour, textbook 3rd edition, Pg 22-38, John wiley and sons Publication limited, New York.

[6] Davenport T. (1993) Process Innovation Re-engineering Work through information Technology, a Journal of Social Sciences, vol 3 pg 143-156, Massachusetts Harvard Press.

[7] Dawson (1996) Analysing Planning in an Organization, a Journal of Management, university of London, Macmillan Press, Lagos.

[8] Dixon G. (1979) Planning and Management Organization, Sweden business School Publication Wiley and sons Press limited, New York.

[9] Drucker, P.F (2003) The Theory and Practice of Management, a broader perspective, 4th edition, pg 98-114, New York Press

[10] Drucker, P.F (2004) Management, Task, responsibilities and Practices, a textbook 3rd edition, Pg 45-63, New York Harper and Row Publication limited.

[11] Druckr P.F. (1974) Management, Task, responsibilities, and Practices, 1st edition, pg 26-35, London Williams Heinemann Publication.

[12] Drucker P.F. (1995) The theory and Practice of Management, 4th edition, Oxford Butter North Heinemann Publication limited Freadier F.E. (1967) Impact of Leadership on organizational Effectieveness, Journal of college of Management, University of Belgium New York Mcgraw Hill pg 9-18

[13] Geotz, N. (1999) Management and Planning, a propeller for organizational performance, Journal of College of Management Goteburg University, vol 11, pg 23-34, Plymouth Macdonald and Even Publication limited.

[14] Harding H. (1987) Theory and Management of Planning, 3rd edition,pg 44-49, London Pitman Presss limited.

[15] Humbl, J.N. (1967) Management by Objectives, textbook, 2nd edition pg 67-72, London, industrial Education and Research Foundation Publication.

[16] Kapolan, R.S and Nortn, D.P (1993) Putting the Balance Score card to work, Harvard Business Review, pg 134-146, Harvard Publication.

[17] Koontz, H. O’Donnell, C and Weibrich, H (1980) Management in broader perspective, Management of Multidisciplinary study, Tokyo Macgraw Hill Publication limited.

[18] Korman, A.K. (1966) Consideration, initially Structure and Organizational Criteria, A Review of Personnel Psychology, a Journal of Applied Research, pg 349-361, MMT Publication limited.

[19] Lipsey, R. (1963) Introduction to Positive Economics, 2nd edition, pg 33 -38, London Gancida Press Limited.

[20] Luthans, F. (1988) Successful and Effective Real Management, the academy of Management Executive, pg 88-89

[21] McGregor, D. (1960) The Human Side of Enterprise, A Planning process, Journal of Management College of business, vol 4, pg 7691, Mcgraw Hill, Boston MIT Press Mosley, D.C, Pietri P.H and Megginson C.C (1966) Management Leadership in Action,

[22] Harper Collins College Publishers, U S A 5th Edition.

[23] Nash, L. (1988) Mission Statement Mirrors and Windows, Massachusetts, Harvard. Newman, W. (1963) Administrative Action, the techniques of Organization and Management 2nd edition, New Jersey, Prentice Hall

[24] Odiorne, G.S (1965) Management by Objective, a system of Managerial Leadership, textbook, 3rd edition pg 32-41, Pitman Publiching, Odiorne, the human side of Management, San Diego California University associates.

[25] Parkinson, C.N. (1997) Impact of Planning on Organizational performance, Journal of Social Science, vol 5, pg 99-1233, Parkinsonis law, Boston, Houghton Mifflin Publication limited.

[26] Robbins, S (1998) Organizational Behaviour Concepts Controversies Applications, 4th edition, pg 44-57, New Jersey, Prentice Hall international Inc, upper saddle river Publication limited.

[27] Schermerhorn, J (1986) Management for Productivity, a textbook 2nd edition pg 76-89 New York,John wile and sons Publication limited.

[28] Schermerhorn, J (1996) Management and Organizational Behaviour, 2nd pg 227-36, edition New York, Wiley and sons Publication limited.

[29] Schermerhorn, J. (1999) Management in focus, 6th edition pg 44-57, Wiley and sons Inc USA Publication limited.

[30] Schwartz, P (1991) Impact of effective Planning on Organizational Performance, Journal of International Management, vol 3, pg 33-47, New York Double day Publication limited.

[31] Stone, R. (1994) Aids in the work place, an Executive update, New York Management issues vol4, pg 55-78, MacGraw Hill Publication limited.

[32] Stone, G (1963) Top Management Planning and Organization Performance, Journal of University of Management New York, vol 5, pg 110-123 Macmillan Publication limited.

[33] Stoner, J (1982) Management and Planning, a broader perspective, a textbook, 2nd edition, New Jersey, Prentice Hall Publication limited.

[34] Watts, B (1974) Industry and Finance, a imperative perspective, a textbook, 3rd edition, pg 66-75,Plymouth Macdonald and Evans Publication limited. 